\title{
Residual effects of sugar beet vinasse on plant growth
}

\author{
P. Martín-Olmedo, F. Cabrera, R. Lopez \& J.M. Murillo \\ Instituto de Recursos Naturales y Agrobiología de Sevilla (CSIC), Apartado 1052, 4180 Sevilla, Spain
}

Key words: Organic wastes, vinasse, plant nutrition, micronutrients assimilability, tall fescue

\begin{abstract}
Residual effect of a concentrated and depotassified beet vinasse on growth and mineral composition of tall fescue (Festuca arundinacea) was studied. Results were compared with those obtained for a mineral fertilizer treatment and a control. Vinasse and inorganic fertilizer had been previously applied to two different soils at two rates for five years. High doses of vinasse produced the highest yield and the highest concentrations of $\mathrm{P}$ and $\mathrm{K}$ in tissue plant, while decreasing $\mathrm{Na}, \mathrm{Mn}$, and $\mathrm{Zn}$ assimilability.
\end{abstract}

\section{Introduction}

Beet vinasses are effluents from the alcoholic fermen-. tation of sugar beet molasses and their later ethanol destillation. Vinasse causes considerable pollution problems in rivers and lands near alcohol factories because of its high organic matter and total salt contents (Algur and Kadioglu, 1992; Cabrera et al., 1987).

Land application of wastewater is recognized as an important alternative disposal method, both in recycling nutrients essential for plant growth, and in increasing soil fertility (Ward, 1990).

Agronomical use of vinasses is being studied at present for several authors (Algur and Kadioglu, 1992; López et al., 1990, 1992; Murillo et al., 1993). In all cases it was evaluated the possible consequences, on different aspects of the soil-plant system, after a direct application of vinasse. Information on the residual effect of vinasse over a long period of time is lacking, and we iniciated these studies to obtain this information.

\section{Methods}

From 1989 to 1993 , a concentrated and depotassified beet vinasse (density 1.3 ; pH 5 ; dry matter $54 \%$; total organic matter $40 \% ; \mathrm{N} 3.3 \%$; P $0.02 \% ; \mathrm{K} 3.5 \%$ ) was applied to greenhouse containers (ca. $0.42 \mathrm{~m}^{2}$, $50 \mathrm{~cm}$ depth) filled with two topsoils (Table 1): a
Xerorthent (loam-clay-sandy soil, S1) and a Xeropsamment (sandy soil, S2).

During this period, five fertilization treatments in a completely randomized design with five replicates per treatment, were assayed: two rates of beet vinasse (V1 and V2); two rates of a mineral fertilizer (MF1 and MF2 supplying the same amounts of $\mathrm{N}$ and $\mathrm{P}$ as the vinasse treatments); and a control (C), without fertilization. A summary of fertilization during the period 1989-1993 is described elsewhere (López et al., 1990). Ryegrass (Lolium multiflorum) was cropped annually and the yield and nutrient contents of tissue plants determined.

In 1994, (study reported here), the residual effect was evaluated and, thus, no organic or mineral fertilizer was applied. Tall fescue (Festuca arundinacea cv. Manade) was grown in the same containers.

At 76,129 and 172 days after sowing, tall fescue was clipped to $3 \mathrm{~cm}$ height, weighed and analysed. Plant samples were washed with tap and deionized water, oven dried at $70^{\circ} \mathrm{C}$ for $48 \mathrm{~h}$, and ground to pass through a 40 mesh screen. Nitrogen was determined by Kjeldahl digestion. Mineral elements were determined according to Jones et al. (1991).

From dried weight and nutritional mineral content in tissue plants, nutrient extraction at each clipping and the total nutrient extraction were determined.

The data were subjected to analysis of variance and the mean separation performed by the Tuckey test. A 
Table 1. Soils Characteristics

\begin{tabular}{|c|c|c|c|c|c|c|c|}
\hline \multirow[t]{2}{*}{ Soil } & \multirow[t]{2}{*}{ Treat. } & $N$ & $\mathbf{P}$ & $\mathrm{K}$ & \multirow{2}{*}{$\begin{array}{l}\text { O.M. } \\
(\%)\end{array}$} & \multirow[t]{2}{*}{$\mathrm{pH}$} & \multirow{2}{*}{$\begin{array}{l}\text { E.C. } \\
(1.5)\end{array}$} \\
\hline & & \multicolumn{3}{|c|}{$(\mathrm{mg} \mathrm{kg}-1)$} & & & \\
\hline \multicolumn{8}{|c|}{ Initial conditions } \\
\hline S1 & - & 536 & 2.5 & 170 & 0.53 & 7.90 & - \\
\hline S2 & - & 347 & 3 & 47 & 0.14 & 8.45 & - \\
\hline \multicolumn{8}{|c|}{ After five years of treatment } \\
\hline \multirow{5}{*}{$\mathrm{S} 1$} & C & 689 & 3 & 91 & 1.29 & 7.29 & 0.80 \\
\hline & VI & 772 & 8 & 91 & 2.07 & 7.69 & 0.48 \\
\hline & $\mathrm{V} 2$ & 746 & 20 & 125 & 1.24 & 7.49 & 0.59 \\
\hline & $\mathrm{MF} 1$ & 674 & 9 & 108 & 1.52 & 7.68 & 0.64 \\
\hline & MF2 & 746 & $14:$ & 91 & 1.47 & 7.78 & 0.43 \\
\hline \multirow{2}{*}{ : } & C & 646 & 5 & 75 & 0.81 & 8.04 & 0.14 \\
\hline & $\mathrm{V} 1$ & 524 & 8 & 50 & 0.62 & 7.93 & 0.24 \\
\hline \multirow[t]{3}{*}{ S2 } & $\mathrm{V} 2$ & 786 & 33 & 66 & 0.93 & 7.96 & 0.20 \\
\hline & $\mathrm{MFl}$ & 495 & 7 & 50 & 0.53 & 8.07 & 0.20 \\
\hline & $\mathrm{MF2}$ & 480 & 11 & 42 & 0.84 & 7.91 & 0.23 \\
\hline
\end{tabular}

Table 2. Effects of different treatments and soil type on elemental composition of tall fescue at selected clipping

\begin{tabular}{|c|c|c|c|c|c|c|c|}
\hline \multirow[t]{2}{*}{ Clip } & \multirow[t]{2}{*}{ Treat. } & $N$ & $\mathrm{P}$ & $\mathrm{K}$ & $\mathrm{Na}$ & $\mathrm{Mn}$ & $\mathrm{Zn}$ \\
\hline & & \multicolumn{4}{|c|}{$\%$} & \multicolumn{2}{|c|}{$\mathrm{mg} \mathrm{kg}^{-1}$} \\
\hline \multicolumn{8}{|c|}{ Soil SI } \\
\hline \multirow{5}{*}{1} & $\mathrm{C}$ & $3.63 \mathrm{a}$ & $0.15 \mathrm{a}$ & $1.83 \mathrm{ab}$ & $1.27 \mathrm{a}$ & $97 \mathrm{a}$ & $74 a$ \\
\hline & $\mathrm{V} 1$ & $3.67 \mathrm{a}$ & $0.26 \mathrm{~b}$ & $1.80 \mathrm{a}$ & $1.38 \mathrm{a}$ & $69 \mathrm{a}$ & 56 a \\
\hline & $\mathrm{V} 2$ & $2.75 \mathrm{a}$ & $0.27 \mathrm{~b}$ & $2.30 \mathrm{~b}$ & $1.11 \mathrm{a}$ & $70 a$ & $48 a$ \\
\hline & $\mathrm{MF} 1$ & $3.23 \mathrm{a}$ & $0.24 \mathrm{~b}$ & $1.44 \mathrm{a}$ & $1.47 \mathrm{a}$ & $88 \mathrm{a}$ & $64 a$ \\
\hline & $\mathrm{MF} 2$ & $3.56 \mathrm{a}$ & $0.25 \mathrm{~b}$ & $1.48 \mathrm{a}$ & $1.40 \mathrm{a}$ & $99 \mathrm{a}$ & $48 a$ \\
\hline \multicolumn{8}{|c|}{ Soil S2 } \\
\hline \multirow{5}{*}{2} & $\mathrm{C}$ & $3.30 \mathrm{~b}$ & $0.11 \mathrm{a}$ & $2.06 a$ & $0.37 \mathrm{a}$ & $112 \mathrm{~b}$ & $61 \mathrm{~b}$ \\
\hline & $\mathrm{VI}$ & $2.22 a$ & $0.18 b$ & $1.81 \mathrm{a}$ & $0.51 \mathrm{ab}$ & $67 a$ & $30 a$ \\
\hline & $V_{2}$ & $2.14 \mathrm{a}$ & $0.25 \mathrm{c}$ & $1.98 \mathrm{a}$ & $0.43 \mathrm{a}$ & 61 a & $30 a$ \\
\hline & MF1 & $2.35 \mathrm{a}$ & $0.16 \mathrm{ab}$ & $1.79 \mathrm{a}$ & $0.58 \mathrm{~b}$ & $83 a$ & $39 a$ \\
\hline & $\mathrm{MF2}$ & $2.28 \mathrm{a}$ & $0.17 \mathrm{ab}$ & $1.73 \mathrm{a}$ & $0.48 \mathrm{ab}$ & $77 \mathrm{a}$ & $30 \mathrm{a}$ \\
\hline
\end{tabular}

significance level of $p<0.05$ was considered throughout the study.

Multivariant Discriminant Analysis of total nutrient extraction data was carried out by the Statgraphics computer program (Statgraphics, 1989).
Results and discussion

Yields

Yield of tall fescue was higher in soil S1 (loam-claysandy soil) than in soil S2: mean grass weight averaged over all treatments and clippings was $1427 \mathrm{~kg} \mathrm{ha}^{-1}$ for 
Table 3. Standardized discriminant coefficients.

\begin{tabular}{lrrrr}
\hline \multicolumn{4}{c}{ Soil SI } & \multicolumn{2}{l}{ Soil S2 } \\
\hline Variables & \multicolumn{1}{c}{$\mathrm{F} 1$} & \multicolumn{1}{l}{ F2 } & \multicolumn{1}{l}{ F1 } & \multicolumn{1}{l}{ F2 } \\
\hline $\mathrm{N}$ & 1.17674 & 0.19223 & -1.87844 & 0.74230 \\
$\mathrm{P}$ & 2.31942 & 0.28398 & 2.69114 & 0.89905 \\
$\mathrm{~K}$ & -0.71408 & -1.59387 & 1.80433 & -0.37005 \\
$\mathrm{Na}$ & 1.90686 & 0.53361 & 0.01545 & -0.54487 \\
$\mathrm{Ca}$ & -1.03744 & 0.96591 & -3.93211 & 0.03535 \\
$\mathrm{Mg}$ & -0.67652 & -0.19034 & -0.14766 & 0.41729 \\
$\mathrm{Fe}$ & -0.54362 & -1.10567 & -0.44199 & -0.85139 \\
$\mathrm{Cu}$ & -0.88883 & -0.01157 & 0.54742 & -0.18079 \\
$\mathrm{Mn}$ & 0.53283 & 0.67540 & 0.08617 & 0.25144 \\
$\mathrm{Zn}$ & -0.96473 & 0.09336 & 1.05669 & 0.38216 \\
\hline Variance (\%) & 88.48 & 10.03 & 48.69 & \multicolumn{1}{c}{42.91} \\
\hline
\end{tabular}

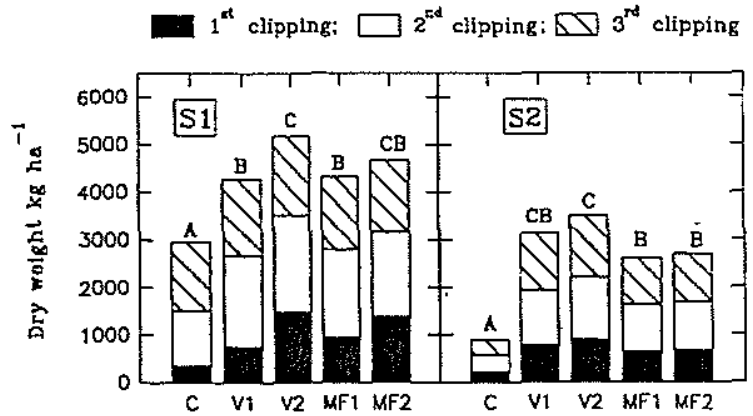

Fig. 1. Dry weight of tall fescue biomass for each treatment in soil $\mathrm{S} 1$ and $\mathrm{S} 2$.

$\mathrm{S} 1$ and $854 \mathrm{~kg} \mathrm{ha}^{-1}$ for S2. Earlier laboratory incubation studies showed a much higher $\mathrm{N}$ release from the mineralization of the residual organic $\mathrm{N}$ in soil $\mathrm{S} 1$ than in soil S2 after three years of treatment with V, MF and C (Martín-Olmedo et al., 1995). Furthermore, increases in tall fescue growth as the soil clay content increased were also observed by other authors (Devitt et al., 1990; Tester et al., 1982).

The mineralization process, slower in soil S1 than in soil S2 due to a higher protection of the organic matter and soil biomass (Martín-Olmedo et al., 1995), might be responsible for greater differences in soil \$2 between organic (V1 and V2) and mineral (MF1 and MF2) fertilizer treatments.

Maximum yields at each harvest clipping (Fig. 1) corresponded, in both soils, to the high vinasse rate (V2), in agreement with previous studies (MartínOlmedo et al., 1995) in which potentially mineraliz- able nitrogen, total- $\mathrm{N}$ and organic matter were higher in soils treated with vinasse than in those treated with mineral fertilizer or control. V1 and MF1 produced almost equal yields, being both statistically higher than the control.

No phytotoxicity was observed after long-term vinasse application, ratifying anterior experiments (Lopez et al., 1992).

\section{Nutritional stage}

The intrinsic soil fertility, greater in S1 than in S2, is responsible for greater levels of macro and micronutrients in plants grown in soil S1 (Table 2).

A decrease of the Fescue Nitrogen Content (FNC) was observed along the growth period. In the first clipping FNC values for all the treatments were within the proposed critical range (2.8-3.4\%) (Martin \& Matocha, 1973), while in further clippings, FNC values, excepting for the control, were below that range. In general, an inverse relationship between dry matter weight and FNC was observed: lowest FNC was registered for V2 treatment as a dilution effect (Jarrel \& Beverly, 1981). Similar results were reported by Eck $e t$ al. (1981) in fescue and by Lund \& Doss (1980) in rye. These low values at the end of the experiment were most likely due to reduced $\mathrm{N}$ release from residual $\mathrm{N}$ of soils with time, and to the possible presence of dead and senescent tissues in the final harvest (Devitt et al., 1990). 


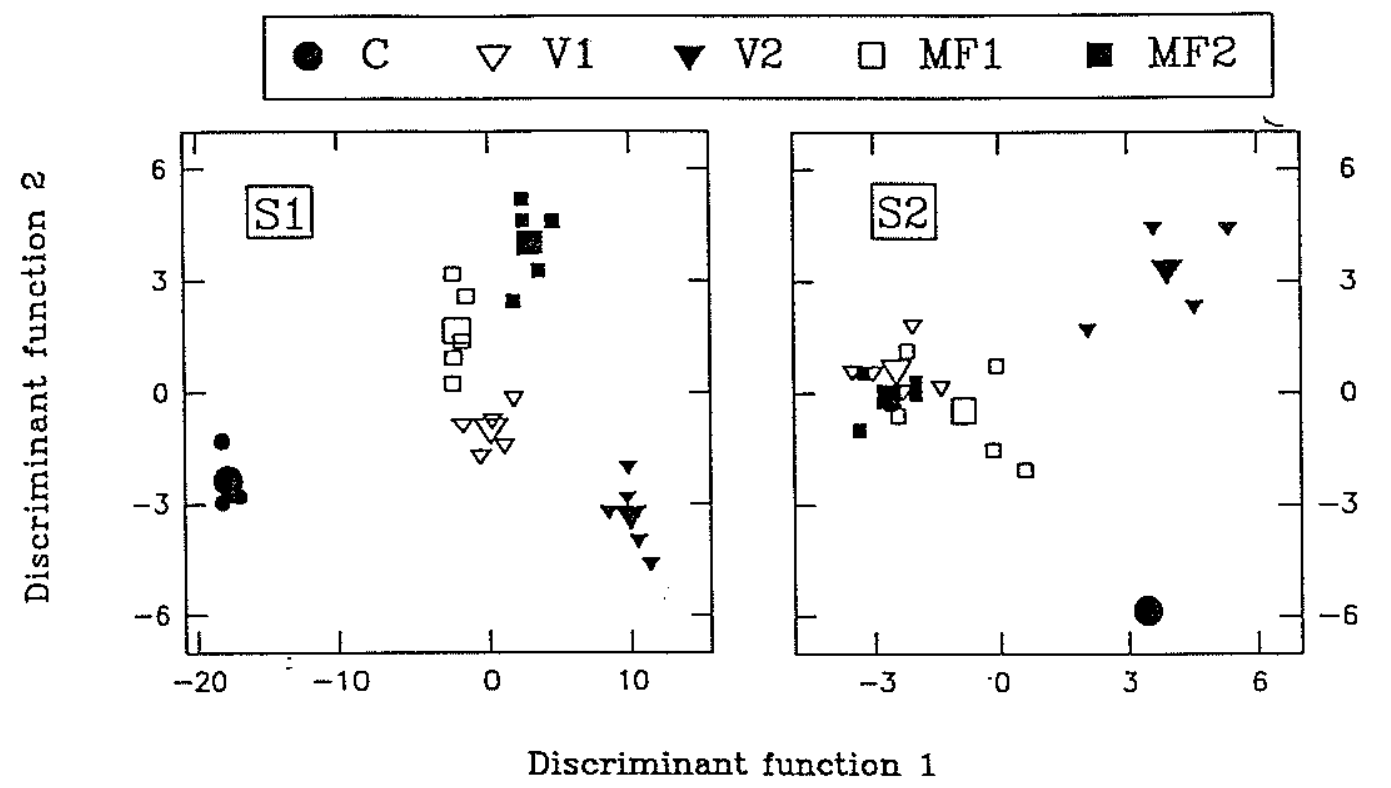

Fig. 2. Discriminant analysis of total nutrient extraction data (Big symbols correspond to group centroids).

Vinasse treatments showed the highest $\mathrm{P}$ and $\mathrm{K}$ concentration in fescue. High values of $\mathrm{P}$ could be related to the acidic $\mathrm{pH}$ of vinasse, while high values of $\mathrm{K}$ are related to the high $\mathrm{K}$ content of vinasse. Both sets of values were lower than the established critical ranges: $0.26-0.32 \% \mathrm{P}$ and $2.5-2.8 \% \mathrm{~K}$ (Martin and Matocha, 1973).

$\mathrm{Mn}$ and $\mathrm{Zn}$ contents were lower for vinasse treatments. This fact could be attributed to the presence of complexing agents in the residual organic matter (Atkinson et al., 1958).

\section{Extraction}

Multivariant discriminant analysis shows that function $F 1$ and $F 2$ explain the $98.5 \%$ and $91.6 \%$ of the variance in soil S1 and soil S2 respectively (Table 3).

Plot F1 vs F2 display a visual separation of the population data of the different treatments (Fig. 2). Analysing the standardized discriminant coefficients for all variables defining function 1 and 2 (Table 3), allows the discernment of the most determinant variables in the separation of the treatments. V2 treatment, which has extracted significantly the greatest amount of $N, P$, and $K$, is obviously the best differentiated from the rest of treatments in both soils.

\section{Acknowledgements}

The authors acknowledge the Comission Interministerial de Ciencia y Tecnología of Spain for financial support (Project No. AGR91-0600). P. Martín-Olmedo gives thanks for the grant received from the Ministerio de Educación y Ciencia of Spain.

\section{References}

Algur OF and Kadioglu A (1992) The effects of vinasse on the growth, biomass, and primary productivity in pea (Pisum sativum) and sunflower (Helianthus annuus). Agr Ecosyst Environ 39: 139-144.

Atkinson HJ, Giles GR and Desjardins JO (1958) Effect of farnyard manure on the trace elements content of soil and plants grown there-on. Plant Soil 10: 32-36.

Cabrera F, Moreno F, Nacci S and De Arambarri P (1987) Utilization of wastes from olive and sugar beet processing industries in fertirigation. Proc 4th International CIEC Symposium, Braunschweig, pp 475-483.

Devitt DA, Morris RLI and Bouwman DC (1990) Response of tall fescue to composted sewage sludge used as a soil amended. $J$ Plant Nut 13: 1115-1139.

Eck HV, Martinez T and Wilson GC (1981) Effect of fertilization and harvest frecuency on yield and quality of tall fescue and smooth bromegrass. Commun Soil Sci Plant Anal 12: 537-555.

Jarrel WM and Beverly RB (1981) The dilution effect in plant nutrition studies. Adv Agron 34: 198-224.

Jones Jr JB, Wolf B and Mills HA (1991) Plant Analysis Handbook. G.A. Micro-Macro Publishing, Athens, Georgia, USA.

Lopez R, Cabrera F, Moreno S, Esenarro G and Llorente MM (1992) Efecto de la fertilización con vinaza concentrada sobre la produc- 
ción y estado nutricional de ryegrass. Proc Cong Nacional Ciencia del Suelo, Pamplona 220-225.

Lopez R, Cabrera F, Murillo JM and Machuca MJ (1990) Utilizacion como abono de vinaza concentrada. I Intern. Cong de Química de la ANQUE, Tenerife, vol II pp 223-232.

Lund ZF and Doss BD (1980) Residual Effect of Dairy Cattle Manure on Plant Growth and Soil Properties. Agron J 72: 123-130.

Martin WE and Matocha JE (1973) Plant Analysis as an Aid in the Fertilization of Forage Crops. In Soil Testing and Plant Analysis Walsh LM (ed.), Soil Sci Soc Am, Madison, pp 393-425.

Martín-Olmedo P, L6pez R, Cabrera F and Murillo JM (1995) Nitrogen mineralization in soils anended with organic by-products of olive oil and sugar beet processing industries. Fresenius Environ Bull 4: 59-64.

Murillo JM, Cabrera F and Lopez R (1993) Effect of beet vinasse on Germination and seedling perfornance of ryegrass (Lolium multifiorum). I Sci Food Agric 61: 155-160.

Statistical Graphics Corporation (1986) Statgraphics 2.1 User's guide, U.S.A.

Tester CF, Sikora LJ, Taylor JM and Parr JF (1982) Nitrogen utilization by tall fescue from sewage sludge compost amended soils. Agron J 74: 1013-1018.

Ward R (1990) Use of wastes in agriculture. Book of Proceedings 10th World Fertilizer Congress of CIEC, Nicosia 477-489. 